\title{
SPATIAL RESOLUTION AND MEASUREMENT ACCURACY OF THE ULTRASOUND DIAGNOSTIC SYSTEM AT ACOUSTIC REMOTE PALPATION USING HIGH INTENSITY FOCUSING ULTRASOUND
}

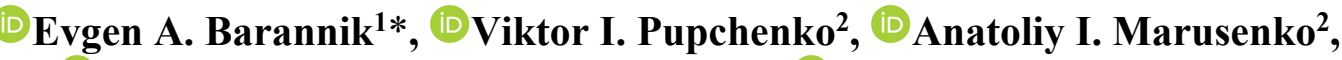 \\ (iD) Olexiy V. Knyazyev², Igor M. Tsybin ${ }^{3}$, (D)Aleksandr E. Berkovich ${ }^{4}$ \\ ${ }^{1}$ V.N. Karazin Kharkiv National University, Kharkiv, Ukraine \\ ${ }^{2}$ Ultrasign, Ltd., Kharkiv, Ukraine \\ ${ }^{3} J S C$ "NPF BIOSS", Moscow, Russia \\ ${ }^{4}$ Peter the Great St. Petersburg Polytechnic University, St. Petersburg, Russia \\ *E-mail: ebarannik@ukr.net
}

Received November 10, 2019; revised November 12, 2019; accepted November 22, 2019

In this work the spatial resolution and measurement accuracy of the ultrasound diagnostic system at acoustic remote palpation (ARP) using high-intensity focusing ultrasound (HIFU) are studied theoretically and experimentally. A physical model is proposed, which describes the specific features of ARP taking into account the remote nature of ultrasound Doppler probing of the soft tissues local movements, which are caused by the radiation pressure of HIFU pulse. Taking into account the accepted simplifying assumptions it is shown that the model conclusions are in a good agreement with the results of the experiments on measuring the value of displacements under the influence of HIFU. In particular, the nontrivial dependence of the value of displacements, measured by the Doppler method, on the probing depth and focusing degree of the incident and scattered wave beams, is proved. An experimental study was performed on the transverse resolution at ARP in the case of probing of the medium with Young's modulus irregularity, as well as on the influence of noise and interference on the measurement accuracy and resolution. It is concluded, that the transverse resolution at ARP is determined by the parameters of the local area of the movement, and can be significantly higher than the transverse intrinsic resolution of the ultrasound system at B-mode of diagnostics. The obtained results indicate that ARP is a promising method for monitoring the process of the soft tissues thermal ablation, when HIFU is used.

KEY WORDS: ARP, HIFU, ablation, Doppler probing, elastography, spatial resolution, measurement accuracy

Nowadays the techniques based on the high-intensity focusing ultrasound (HIFU) are widely used in medicine and are still intensively developed towards expanding the scope of medical applications. For example, it has been demonstrated in vivo and in vitro, that within a few minutes the short-pulse HIFU can mechanically crush the blood clots, caused by blood vessel thrombosis, due to the developing cavitation processes [1-4]. An important task here is providing safety of HIFU application in order to prevent the involvement of biological tissues outside the defined local area, what requires strong focusing of ultrasound waves.

At the same time, the most common and well-known technology is the ultrasound ablation of soft tissues [5-11] using HIFU through_coagulation necrosis of malignant neoplasms and other soft tissue regions with pathological changes. Strong wave focusing and high radiation intensity in such traditional medical applications are necessary to achieve high temperature (about $80^{\circ}-90^{\circ} \mathrm{C}$ ) in the focal region resulting in thermal ablation of soft tissue. Nevertheless, the real-time monitoring of the thermal ablation process and the tissues state diagnostics remains one of the topical questions. Insufficient exposure can cause a relapse and even an accelerated growth of the neoplasms, while the excessive exposure can cause the involvement of the neighboring healthy tissues.

As it is known, the most common methods in diagnostics of the soft tissues and cardiovascular system are ultrasound methods. They are, in particular, ultrasound Doppler methods, including spectral Doppler studies, color Doppler mapping of blood flows and some others, whose physical properties are described, for example, in [12-15]. The Doppler methods are successfully applied and developed also for diagnostics of the soft tissue state [16-18]. At the same time, considering the intrinsic physical meaning of ultrasound methods [19], it is quite difficult to directly determine directly with their help the level of the biological tissue thermal destruction.

Recently, in ultrasonic medical diagnostics the methods of ultrasound elastography of soft tissues, such as acoustic radiation force impulse (ARFI) imaging [20-22] and shear wave elastography (SWE) [22-24], have been widely used. These methods are based on ultrasound registration of the soft tissue response to the radiation force of an ultrasound pulse, and in the both methods the same ultrasound transducer of the diagnostic system is used for both creation of the radiation pressure force and registration of the response [20]. The difference is in the fact, that in the ARFI method the value of the tissue displacement is measured directly at the region of the radiation force pulse impact, while at SWE the velocity of the shear wave, propagating in the tissues from the initial region of the force impact, is measured.

In [25] for monitoring the process of tissue thermal ablation it has been proposed to use a diagnostic system, which measures the value of the tissue displacement at the region of the radiation force impact, generated directly by the HIFU. It was shown experimentally [25], that under local heating up to the temperature of $43^{\circ} \mathrm{C}$, the value of the maximum displacements in the muscle tissue of a cow in vitro changes, what indicates to a change in its viscoelastic properties. Earlier, a similar strong dependence of the value of displacements and the velocity of shear waves on the growth of temperature, caused by the HIFU exposure, was found in gelatinous phantoms of tissue [26].

The focal length of the real HIFU transducers, used for ablation of soft tissue, can reach a large value, of about $10-20 \mathrm{~cm}$. This naturally requires solving the problem on the spatial resolution of the ultrasound Doppler diagnostic (C) Evgen A. Barannik, Viktor I. Pupchenko, Anatoliy I. Marusenko, Oleksiy V. Knyazyev, Igor M. Tsybin,

Aleksandr E. Berkovich, 2019 
system and on the accuracy of measuring the value of tissue displacement in the HIFU focal region at acoustic remote palpation (ARP), carried out using HIFU transducers.

\section{PHYSICAL MODEL}

When describing the ultrasound response of soft tissues, the continual physical model of scattering by fluctuations in mass density and compressibility is generally accepted [27], which allows, in particular, to describe in detail the spectral characteristics of Doppler signals [13-15,28,29]. A distinctive feature of both ARFI and ARP is the fact, that the direction of tissue movement under the radiation force impact coincides with the direction of probing. If we neglect the geometrical and transit time spectral broadening [13.27] of the complex signal of ultrasound Doppler response, then in the plane-wave approximation it can be written in a simple form:

$$
e\left(\varphi^{\prime}\right)=\int_{S} g(\vec{r}) e^{i \varphi(\vec{r})} d S,
$$

where $g(\vec{r})=g_{0}(\vec{r}) \exp (i 2 k d)$ is the dimensional complex value, proportional to the diagnostic system sensitivity function, averaged over the sample volume in the direction of probing; $O x, d$ is the probing depth along the probing direction; $k$ is the wave number; $\varphi(\vec{r})=2 k u(\vec{r})$ is the phase of a local Doppler signal, depending on the local tissue displacement $u(\vec{r})$, and $\varphi^{\prime}$ is the phase of the complex signal of the full Doppler response, having the in-phase and quadrature components. In expression (1) the integration is carried out over the cross-sectional area of the sample volume, therefore $\vec{r}$ is the coordinate of the area element $d S$ in the plane of section $(y, z)$, and the actual value $g_{0}(\vec{r})$ describes the spatial distribution of ultrasound fields in the plane of section and determines the transverse resolution of the ultrasound system in the usual B-mode. Note, that the real signal of the ultrasonic Doppler response is also proportional to the average level of the medium density and compressibility fluctuations.

The transverse dimensions of the area of the radiation force impact for the real HIFUs are of the order of 1-1.5 mm. Therefore, a specific feature of ARP, as compared to ARFI, is the fact, that the transverse dimensions of the local displacement region and, accordingly, its cross-sectional area $S_{0}$ at the probing depth, can be considered small: $S_{0} \ll S$. In particular, the transverse resolution of the ultrasound diagnostic system depending on the probing depth, the degree of focusing, and the ultrasound frequency is of the order of 3-7 mm, what results in a large difference in the value of the areas. This allows to write down the contribution of the localized region of displacements under the influence of HIFU in (1) as a separate term

$$
e\left(\varphi^{\prime}\right)=\int_{S-S_{0}} g(\vec{r}) e^{i \varphi(\vec{r})} d S+g(\vec{R}) S_{0} e^{i \varphi},
$$

where $\vec{R}$ is the coordinate of the center of the radiation force impact region in the sectional plane, $\varphi$ is Doppler phase of the signal from the region of the force impact and $g(\vec{R}) S_{0}$ is the complex amplitude of the response from the region of the force impact. In the remaining integral $\varphi(\vec{r})=0$, as long as it describes the contribution of those areas of the measuring volume, where there is no movement. As a result, we have the equation:

$$
e\left(\varphi^{\prime}\right)=\bar{g}(\vec{R})\left(S-S_{0}\right)+g(\vec{R}) S_{0} e^{i \varphi},
$$

where $\bar{g}(\vec{R})$ is the average value of the response amplitude in the cross section of the measuring volume minus $S_{0}$ area. It is evident, that such an average value also depends on the position of the center of the radiation force impact.

The value of the displacement between two sequential probes can be determined using the Doppler phased tracking method [19,30]) by calculating the correlation function $C=e^{*}\left(\varphi^{\prime}\right) e\left(\varphi^{\prime}+\Delta \varphi^{\prime}\right)$, where $\varphi^{\prime}(\vec{R})$ is the phase of the observed Doppler signal at the first probing, which depends on the location of the displacement region, and $\Delta \varphi^{\prime}(\vec{R})$ is the change in this phase. In accordance with the phased tracking method, the phase change of the Doppler signal is described by the formula:

$$
\operatorname{tg} \Delta \varphi^{\prime}(\vec{R})=\frac{\operatorname{ImC}}{\operatorname{ReC}} .
$$

It is easy to show that, taking into account that the area $S_{0}$ is small, the greatest contribution to the real part of the correlation function is made by the term:

$$
R e C=\bar{g}_{0}(\vec{R})^{2}\left(S-S_{0}\right)^{2} \cong \bar{g}_{0}(\vec{R})^{2} S^{2} .
$$

When calculating the imaginary part, with the strict inequality $S_{0} \ll S$ taken into account, we can neglect the quadratic $S_{0}$ terms. In this approximation we find:

$$
\operatorname{ImC}=\bar{g}_{0}(\vec{R}) g_{0}(\vec{R}) S S_{0}[\sin \varphi(\cos \Delta \varphi-1)+\cos \varphi \sin \Delta \varphi] .
$$

where $\Delta \varphi=2 k \Delta u$ is the change in the phase of the Doppler response of the movement region, which is determined by the true tissue displacement $\Delta u$. 
The phase increment between two sequential probes, virtually in all important cases, satisfies the strong inequality $\Delta \varphi \ll 1$, therefore the first term on the right-hand side of formula (5) can be neglected. As a result after substituting (4) and (5) into (3), we find:

$$
\operatorname{tg} \Delta \varphi^{\prime}(\vec{R})=\frac{g_{0}(\vec{R}) s_{0}}{\bar{g}_{0} S} \cos \varphi \sin \Delta \varphi \ll 1
$$

Taking into account that the phases $\Delta \varphi^{\prime}(\vec{R})$ and $\Delta \varphi$ are small, it is easy to write down the relationship directly between the true and the measured displacements during the probing period as follows:

$$
\Delta u^{\prime}(\vec{R})=\frac{g_{0}(\vec{R}) S_{0}}{\bar{g}_{0}(\vec{R}) S} \cos (2 k u) \Delta u .
$$

The total displacement in the process of observation is obtained by summing the displacements from the start of the movement to the value $u$ at any moment of the displacements registration. Taking into account, that the displacements are small, we can turn from summing small increments (7) to integrating, what results in the final equation for the observed displacement:

$$
u^{\prime}(\vec{R})=\frac{g_{0}(\vec{R}) S_{0}}{\bar{g}_{0}(\vec{R}) S} \int_{0}^{u} \cos (2 k u) d u=(2 k)^{-1} \frac{g_{0}(\vec{R}) s_{0}}{\bar{g}_{0}(\vec{R}) S} \sin (2 k u) .
$$

Equation (8) determines the accuracy of the displacements measurement during ARP without taking into account the influence of noise and interference. Directly from (8) we also obtain the formulae:

$$
\frac{u^{\prime}(\vec{R})}{u^{\prime}(0)}=\frac{g_{0}(\vec{R})}{g_{0}(0)} \frac{\bar{g}_{0}(0)}{\bar{g}_{0}(\vec{R})} .
$$

As it is known, the transverse spatial resolution of the ultrasound diagnostic system is determined by the width of the point spreading function. In the above discussion the role of the point source was played by a rather well-localized region of the tissue displacements, induced by the radiation force impact. In this sense, equation (9) describes the transverse resolution of the diagnostic system at ARP in the case, when the displacements are determined at different spatial positions of the probing transducer axis relative to the axis of HIFU and the region of tissue movement.

However, according to the meaning of the problem of monitoring the ablation process, the issue concerning the ability to distinguish the stiff (soft) Young's modulus irregularities on the homogeneous soft (stiff) background in the area under study is, obviously, more important. According to the physical meaning, in such a formulation of the experiment the resolution during the ARP is determined by the maximum distance, at which the movement in the soft (stiff) part of the inhomogeneous medium still experiences the braking (accelerating) effect of the adjacent stiff (soft) parts due to the arising internal viscoelastic stresses. At such a definition of the resolution, the axes of the HIFU transducer and of the probing transducer must coincide, what ensures the highest sensitivity and locality of determining the displacements in the tissue area with a given stiffness.

\section{MATERIALS AND METHODS}

In our experiments we used a commercial ultrasound diagnostic scanner Angiodin-Sono/P (JSC "NPF BIOSS", Moscow, Russia) as an ultrasound diagnostic system, which is capable to perform measurement of tissue displacements at SWE and ARFI modes with the accuracy of not worse than $10 \%$. The measurements were carried out in the ultrasonic phantom of soft tissue CIRS Model 049 (CIRS, Norfolk, VA, USA), which is used for elastographic and elastometric studies. The Young's modulus in the region of homogeneity of this phantom and in stiff heterogeneities of a spherical shape with diameter $D=1 \mathrm{~cm}$ was, respectively, $18 \mathrm{kPa}$ and $67 \mathrm{kPa}$. The Doppler probing of the phantom points was carried out using commercial ultrasound transducers P2-4/20APX and P4-9/16 (Prosonic Co., Seoul, Korea) with the carrier frequency of $3.5 \mathrm{MHz}$ (wavelength $\lambda=0.42 \mathrm{~mm}$ ) and $6.5 \mathrm{MHz}(\lambda=0.23 \mathrm{~mm})$, respectively. Due to the developed specialized software, the Angiodin diagnostic scanner control system allowed to fine-adjust all the parameters, necessary for performing ARP, and to measure the displacements at the chosen point of phantom. Like in [23-26], the Doppler probing was synchronized with the HIFU pulses, whose parameters, for example pulse duration, could also vary.

As the HIFU emitter, the focusing ultrasound transducer H-148 (SONIC CONCEPTS, INC., Bothell, WA, USA) with the radiation aperture diameter of $64 \mathrm{~mm}$ and the radius of the radiating surface curvature of $64 \mathrm{~mm}$ was used. In these experiments, the HIFU pulses with the carrier frequency of $2.2 \mathrm{MHz}$ had the duration of $900 \mu$ s at the voltage of the emitter power supply of $20 \mathrm{~V}$. In the center of the HIFU transducer there was a hole (Fig. 1) with the diameter of $20 \mathrm{~mm}$, through which the Doppler probing was performed. To superimpose the axes of the HIFU transducer and the ultrasound transducer of the diagnostic system, a positioning device was used, which allowed to position the probing transducer in the horizontal plane with the accuracy of $0.1 \mathrm{~mm}$, and to change the distance between the probing transducer and the HIFU emitter in the vertical direction.

Figure 2 shows the general scheme of the experiments, from which it can be seen, that the focus of the HIFU emitter is always located at the distance $F_{H I F U}=71 \mathrm{~mm}$ from the upper surface of the emitter holder. The probing depth $d$ was chosen so, that the cross section plane $(y, z)$ of the sample volume of the diagnostic system passed through the focal point of the HIFU. In the process of the measurements the acoustic phantom, the HIFU emitter, and the working surface of the probing transducer were located in a container with water. 


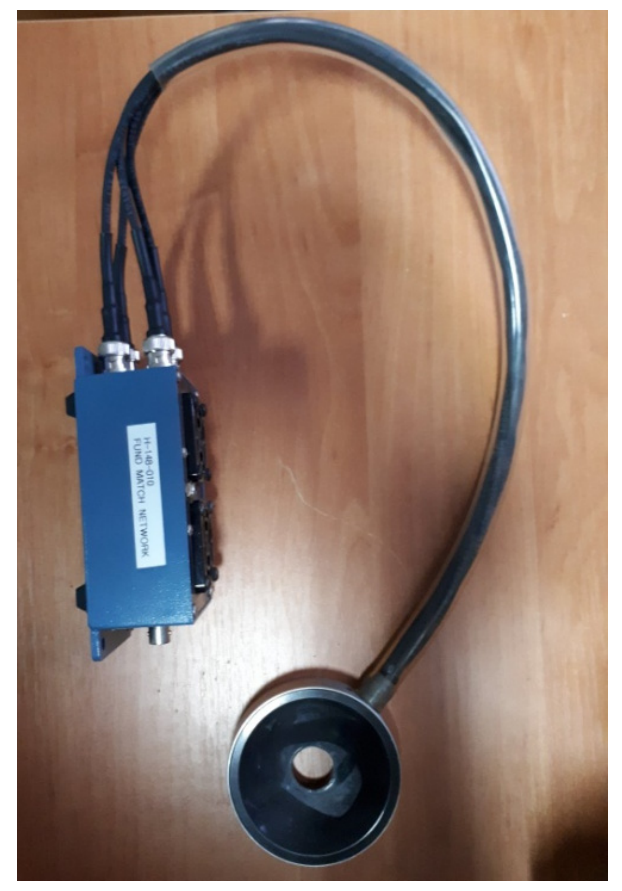

Fig. 1. HIFU Emitter

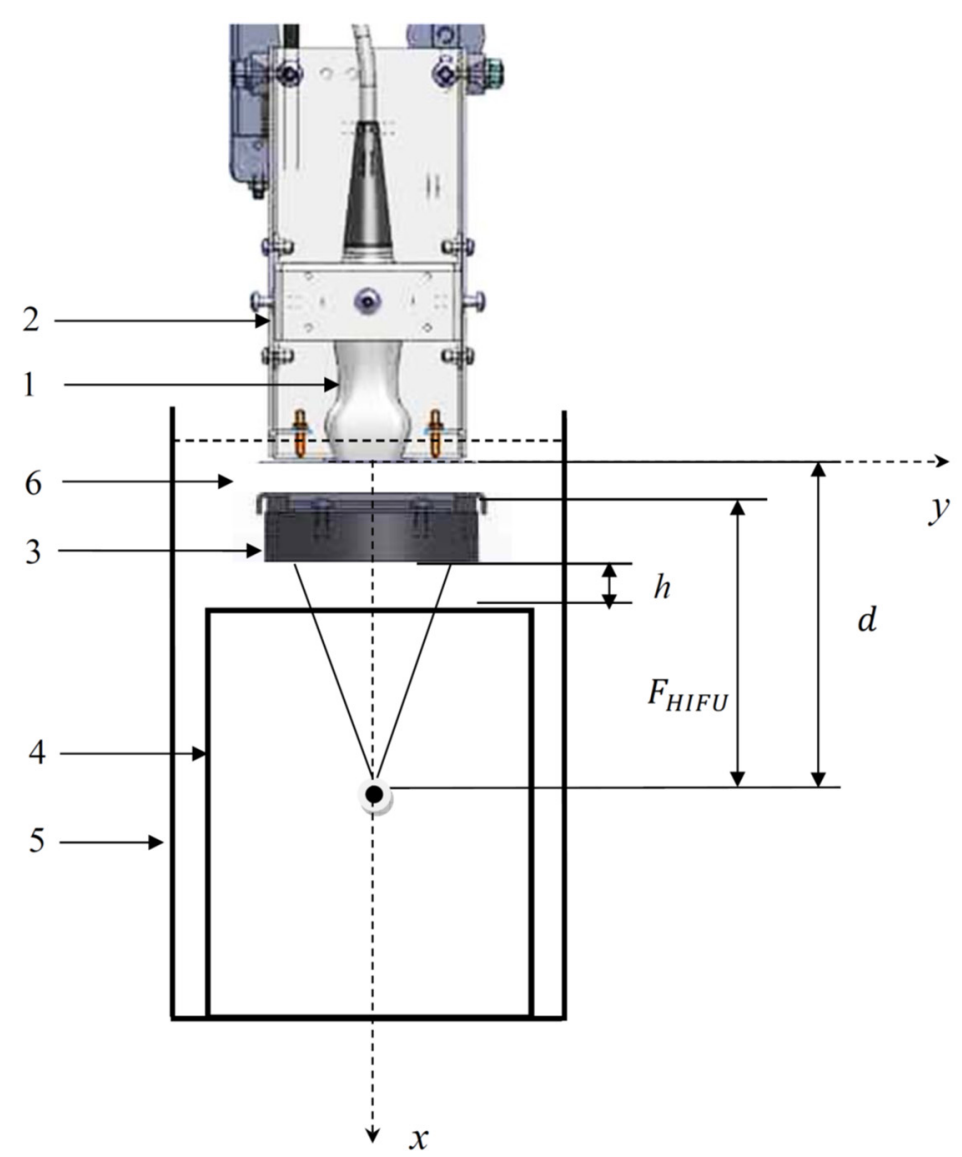

Fig. 2. General scheme of the experiments

1 - probing ultrasound transducer; 2 - ultrasound transducer holder; 3 - holder with the HIFU transducer; 4 - ultrasound soft tissue phantom; 5 - container with water; 6 - water.

\section{EXPERIMENTAL RESULTS AND DISCUSSION}

From expression (8) it follows, that the displacements, measured at ARP, are always smaller than the true ones, and strongly depend on the ratio of the areas $S_{0}$ and $S$. With an increase in the area of the diagnostic system focal spot the value of the measured displacements decreases. This specific property of the measurements at ARP is illustrated by the Table data, which show the value of the measured maximum displacements, during their registration, in the region of phantom homogeneity at the probing depth $d=78 \mathrm{~mm}$. The measurements were carried out under conditions, when the holder of the HIFU transducer was located directly on the phantom surface $(h=0)$. The largest displacement $u^{\prime}(0)=12.9 \mu \mathrm{m}$ in the HIFU focal region was found at electronic focusing by the P2-4/20APX transducer both of the transmitted and of the received beams of ultrasound waves with the focal length $F=d=78 \mathrm{~mm}$. Switching-off at least one focusing (infinity focusing, $F=\infty$ ) caused a decrease in the value of the measured displacements due to an increase in the width of the sample volume, formed by the probing wave beams. When the electronic focusing of both the transmitted and received wave beams was switched off, the value of the measured displacements significantly decreased to the value $u^{\prime}(0)=3.3 \mu \mathrm{m}$. In this case the probing transducer formed piston-like wave beams, which were similar to the plane waves in the Fresnel zone.

Table

The value of the maximum displacements, measured during their registration, at the probing depth $d=78 \mathrm{~mm}$

\begin{tabular}{|c|c|c|}
\hline Transmitter: $F, \mathrm{~mm}$ & Receiver: $F, \mathrm{~mm}$ & Displacement, $u^{\prime}(0), \mu \mathrm{m}$ \\
\hline 78 & 78 & 12.9 \\
\hline$\infty$ & 78 & 11.7 \\
\hline 78 & $\infty$ & 11.2 \\
\hline$\infty$ & $\infty$ & 3.3 \\
\hline
\end{tabular}

Note, that even in the absence of focusing in the probing plane $(x, y)$ the static focusing always takes place in the plane $(x, z)$, perpendicular to the probing plane, due to the own focusing lens of the probing transducer. For the ultrasound 
transducer P2-4/20APX the corresponding focal length is about $70 \mathrm{~mm}$. That is why the shape of the focal spot is close to a circle, strictly speaking, only if the electronic focusing of the transmitted and received waves with $F=70 \mathrm{~mm}$ is available.

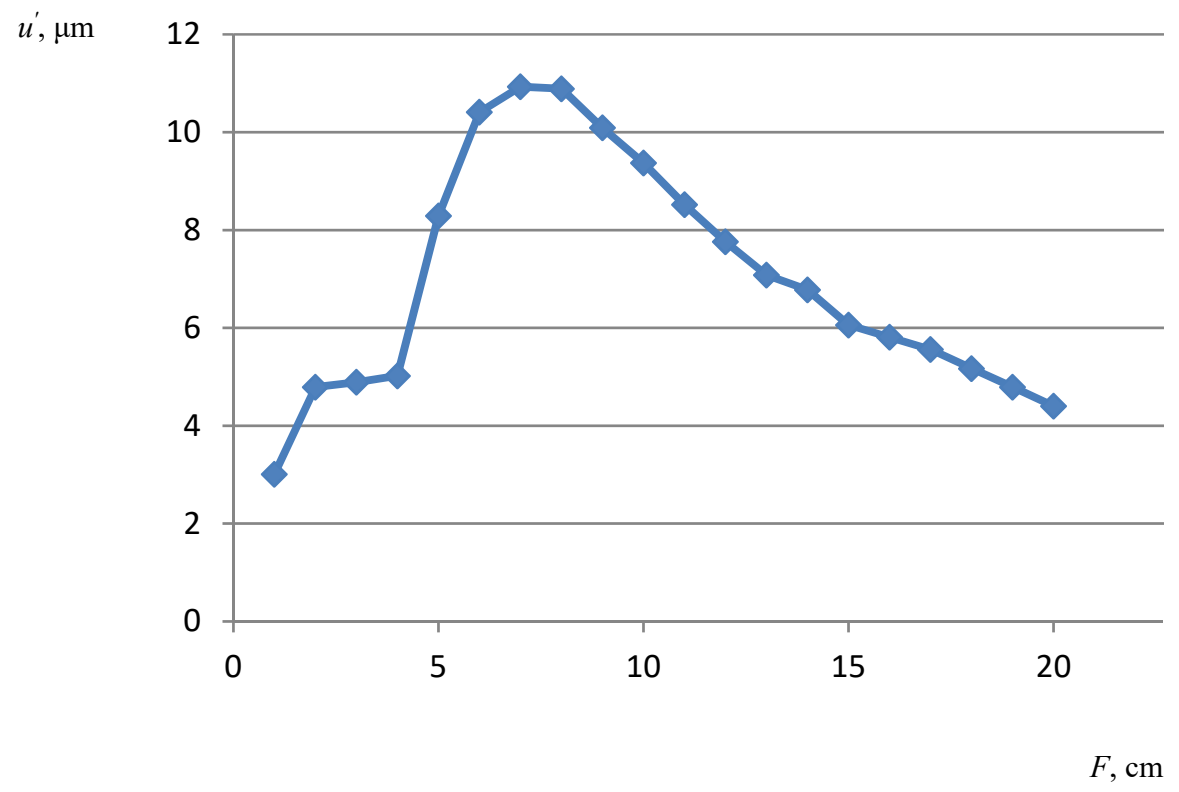

Fig. 3. Dependence of the measured value of displacement in the HIFU focal region on the focal distance of the probing transducer at the constant depth of probing $=78 \mathrm{~mm}$

The results, obtained in the experiments with variable focal lengths (see Fig. 3.), have the same physical meaning as to the value of displacements.

In these experiments the probing depth remained unchanged and was in the focal region of the HIFU under the same experimental conditions and the focal length at transmitting was varied in a wide range (from $10 \mathrm{~mm}$ to $200 \mathrm{~mm}$ ) in the absence of electronic focusing of the received wave beams.

From Fig. 3 it follows, that the measured value of the displacement has a sharp maximum in the HIFU focal region, and drops abruptly as the focus of the probing transducer moves away from it both with a decrease in the focal length and with its increase. In both cases this is due to an increase in the sample volume and its cross section for a defocused beam, both in front of and behind the focal region of the probing transducer. A more abrupt drop at strong focusing (small focal lengths) of the waves is caused by the considerable diffraction divergence of the wave beam behind the focus, and in particular, on the probing depth corresponding to the HIFU focus. At weak focusing of the incident converging wave the beam width changes substantially smaller in a prefocal region, and, as a result, the dependence of the beam width in the HIFU focal region on the focal length is weaker, what also affects the value of the measured displacements.

The ratio $g_{0}(\vec{R}) / g_{0}(0)$ on the right-hand side of equation (9) describes the sensitivity distribution of the ultrasound system in the sectional plane of the sample volume and has a maximum at $\vec{R}=0$. The width of this maximum at the given level determines the transverse spatial resolution of the system at B-mode of diagnostics. The second ratio $\bar{g}_{0}(0) / \bar{g}_{0}(\vec{R})$ also has a maximum at $\vec{R}=0$, as long as the average value of the response amplitude, without the contribution of the area $S_{0}$, increases as its center moves away from the center of the sample volume cross section, where the sensitivity is maximal. As a result, the transverse resolution of the ultrasound diagnostic system, when registering a localized area of movement, can be even a bit higher, than at B-mode of diagnostics.

The experimental data on the transverse distribution of maximum displacements in the probing plane are presented in Fig. 4 for two probing depths $d=F=78 \mathrm{~mm}$ and $d=F=108 \mathrm{~mm}$ at electronic focusing of both transmitted and received wave beams. From these data it follows, that when registering the movement in localized region at the depth of $78 \mathrm{~mm}$, the transverse resolution at the level of $6 \mathrm{~dB}$ is about $4 \div 4.5 \mathrm{~mm}$, and at the depth of $108 \mathrm{~mm}$ it is about $5.5 \mathrm{~mm}$. These values are, at least, not worse, than the transverse resolution at B-mode of ultrasound diagnostics, when using a transducer P2-4/20APX with the same frequency of 3.5 MHz.

Strictly speaking, with a greater probing depth of $108 \mathrm{~mm}$, the value of the displacements, shown in Fig. 4, should be not higher, but lower than that in Fig. 3 due to the larger cross-sectional area of the sample volume. This result can be explained by the influence of noise and, in particular, speckle noise on the measurements accuracy. If the probing transducer is displaced along the probing line so that the sample volume does not completely coincide with the volume, which was set at a lesser depth, then the speckle noise level can change considerably. Another significant factor, affecting the measurements accuracy in these experiments, was the reverberation of ultrasound caused by the reflections from the upper surface of the HIFU transducer. A high level of noises and interferences is indicated, in particular, by the zigzag 
curve in Fig. 4 for the depth of $108 \mathrm{~mm}$. For the same reason, because of a high level of reverberation noise and interference in our experiments, we failed to obtain reliable results for the depths of more than $108 \mathrm{~mm}$.

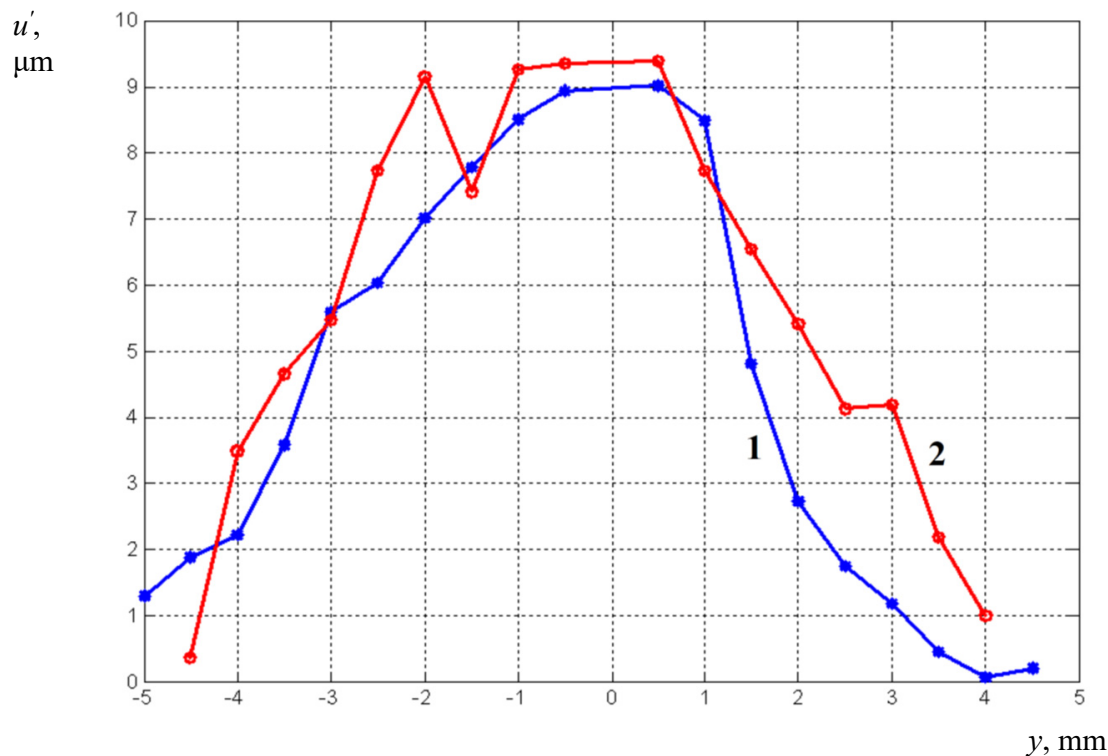

Fig. 4. Distribution of displacements along the direction $O y$ in the probing plane at the depth $d=F=78 \mathrm{~mm}(1)$, and $d=F=108 \mathrm{~mm}$ (2) in the homogeneous part of the soft tissue phantom with localized region of displacements.

The distributions, whose example is shown in Fig. 4, were used to adjust the probing transducer for superimposing its axis with that of the HIFU transducer. To study the transverse resolution of the diagnostic system, when probing the inhomogeneities of shear stiffness in the medium, the probing and HIFU transducers were rigidly fixed relative to each other after aligning the axes, so that the working surface of the probing transducer was directly adjacent to the hole in the HIFU transducer. Such a schematic of the experiment allowed reducing considerably the reverberation noise. As Fig. 2 shows, in this case $d=F=F_{H I F U}=71 \mathrm{~mm}$, and the distance between the lower edge of the holder of the HIFU transducer and the phantom surface was chosen equal to $h=35 \mathrm{~mm}$, what ensured the positioning of the foci of HIFU and probing transducers at the same depth with the center of the stiff spherical inhomogeneity. To find the inhomogeneity in the plane $(y, z)$ we used a B-image of the inhomogeneity and a positioning device, which moved the rigidly connected HIFU and probing transducers.

In these experiments the distributions of the displacement of the phantom material under the influence of HIFU along the both transverse directions $O y$ and $O z$ were determined. To improve the accuracy of the results, the data for 10 depths of probing, spaced $0.4 \mathrm{~mm}$ apart was obtained, so that $d=71 \mathrm{~mm}$ represented the average value. The distributions, obtained using the ultrasonic transducers P2-4/20APX and P4-9/16, are shown in Fig. 5 and Fig. 6, respectively. The red curve in all the figures corresponds to the average value, with the data for all 10 depths of probing taken into account.

First of all, note, that according to the data in Fig. 5 and Fig. 6, the average value of the maximum displacements in the central part of the spherical stiff inhomogeneity is always approximately four times greater, than that in the soft environment, what indicates that ARP is the promising method for controlling the changes in the mechanical properties of the medium under study. On the other hand, this result is in a good agreement with the ratio of the Young's modules for these areas of the used phantom. The inversely proportional dependence of the displacements value on the Young's modulus indicates to the quasistatic nature of the resulting deformation, at which the displacement reaches the maximum value, corresponding to the given force of the radiation pressure due to the sufficiently long pressure pulses [31].

The distributions, shown in Fig. 5 and Fig. 6, as to their meaning, are one-dimensional images of a stiff spherical inhomogeneity inside the soft environment. If the boundary of inhomogeneity of this kind is defined, for example, from the coordinate of the point, at which the displacement corresponds to a certain average value in the soft environment region, then in this case the apparent diameter of the inhomogeneity is equal to $D=12-13 \mathrm{~mm}$. Given the true size of the spherical inhomogeneity, we can conclude that the broadening of its boundary does not exceed 1.0-1.5 mm. An important feature of this result was, that it practically did not depend on the type of the used ultrasonic transducer, on the carrier frequency of the probing wave beams, and on the choice of the transverse direction, along which the distribution of the displacements value was build.

The latter circumstance gives a reason to assert, that the maximum distance, at which the movement, for example, in the soft part of the medium with Young's modulus irregularity can still experience the braking effect of the adjacent stiff inhomogeneity, in our experiments corresponds to the obtained value of $1.0-1.5 \mathrm{~mm}$. In physical terms, this means, that the region of the internal stresses, resulting from the effect of the radiation force, which cause the displacements, and, accordingly, the value of the displacements region itself in our experiments was $2.0-3.0 \mathrm{~mm}$. As it was expected, this 
value was larger than the diameter of the focal region of the HIFU transducer (see, for example, [26, 31]). On the other hand, this result means, that when probing the medium with Young's modulus irregularity using ARP, the resolution is determined by the transverse dimensions of the movement area, formed by a certain HIFU transducer, and therefore can be significantly better than the own spatial resolution of the ultrasound diagnostic system used for the tissue ablation monitoring.
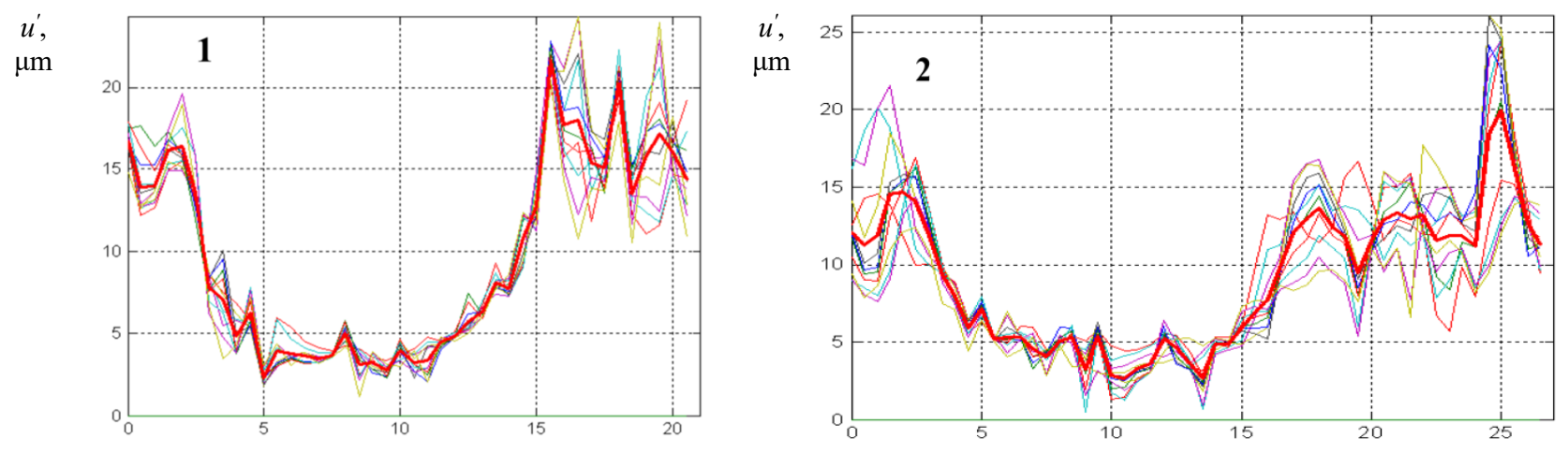

$y, \mathrm{~mm}$

$z, \mathrm{~mm}$

Fig. 5. Transverse distribution of displacements, obtained using a P2-4/20APX transducer, in the region of the inhomogeneity inside the soft tissue phantom at $F=F_{H I F U}=71 \mathrm{~mm}$, and at ten values of the depth of probing, the average depth being $d=71 \mathrm{~mm}$ (red line corresponds to the average distribution): 1 - along the axis $O y ; 2$ - along the axis $\mathrm{Oz}$.
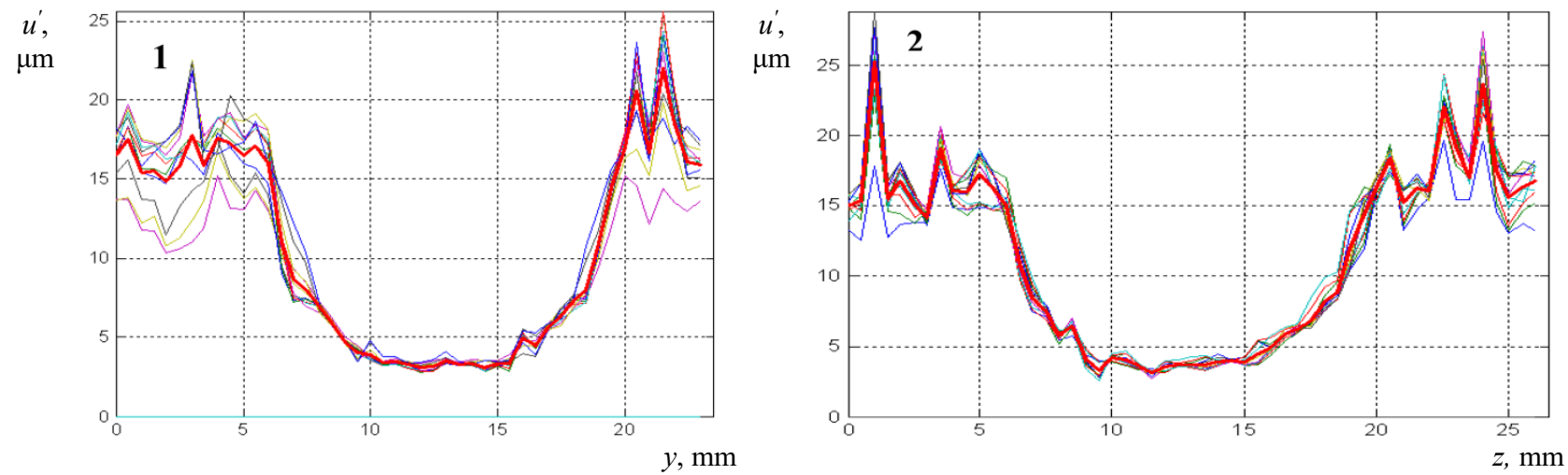

Fig. 6. Transverse distribution of maximum displacements, obtained using a P4-9/16 transducer, in the region of the inhomogeneity inside the soft tissue phantom at $F=F_{H I F U}=71 \mathrm{~mm}$, and at ten values of the depth of probing, the average depth being $d=71 \mathrm{~mm}$ (red line corresponds to the average distribution): 1 - along the axis $O y ; 2$ - along the axis $\mathrm{Oz}$.

In conclusion, we note, that in the focal region of the HIFU the dependence of the measured displacements (8) on the real ones remains monotonically increasing in a fairly wide range of displacements. Under the simplifying assumptions, which we made, the uniform dependence ends when $\varphi_{c}=2 k u_{c}=\pi / 2$, what, for example, at the diagnostic system carrier frequency of $3.5 \mathrm{MHz}$ corresponds to the real displacements of about $50 \mu \mathrm{m}$. With a further increase in the value of the real displacements under the radiation force impact, the determined displacement will decrease according to the sinusoidal law. In this case, when the medium moves back to the equilibrium state, an increase in the measured displacement should be observed until $u_{c}$ value is reached, and then the measured displacements decrease again.

In all our experiments the displacement value was measured for all the moments of time, from the start of the movement under the radiation force impact to the end of the relaxation movement to the equilibrium state, however, the movement of such a pseudo-oscillatory nature was not observed. This means, that the real displacements did not reach the critical value, what was due, in particular, to a sufficiently high stiffness of the used soft tissue phantom. Besides, the critical value of the phase $\varphi_{c}$ is always greater than that of $\pi / 2$, obtained under accepted simplifying assumptions, and grows with the increase of the area $S_{0}$. From formula (2), for example, it follows, that in the limiting case of ARFI, when $S_{0}=S$ and $\vec{R}=0$, the equality $\varphi^{\prime}(0) \equiv \varphi$ is always satisfied, i.e. the critical value is missing. The above results regarding the transverse dimensions of the movement region indicate, that in these experiments the phase value $\varphi_{c}$ was quite high.

\section{CONCLUSION}

In conclusion, we note that in this work, the spatial resolution and measurement accuracy of the ultrasound diagnostic system at ARP are theoretically and experimentally investigated. A physical model is proposed, which describes the specific features of ARP, taking into account the remote nature of ultrasonic Doppler probing of the soft tissues local movements, which are caused by the radiation pressure of a high-intensity focused ultrasound pulse. Taking 
into account the accepted simplifying assumptions, it is shown that the model conclusions are in a good agreement with the results of the experiments on measuring the value of displacements under the influence of HIFU.

In particular, the nontrivial dependence of the value of displacements, measured by the Doppler method, on the probing depth and the focusing degree of the incident and scattered wave beams, in the process of probing the localized region of the movement under the HIFU impact, is proved. An experimental study was performed on the transverse resolution at ARP in the case of probing the medium with Young's modulus irregularity, as well as on the influence of noise and interference on the measurement accuracy and resolution. On the basis of the carried out studies it was concluded, that the transverse resolution at ARP was determined by the transverse dimensions of the of soft tissues movement region, formed by the HIFU transducer, and could be significantly better than the own spatial resolution of the used ultrasound diagnostic system at the B-mode of diagnostics.

In the real commercial soft tissue ablation systems, which use HIFU, the diagnostic probing transducers are built directly into the hole of HIFU transducer, through which ultrasound probing is performed. This allows to avoid the problems with the interference, caused by the reverberation of ultrasound probing wave beams. Taking this circumstance into account, the results, obtained in this work, indicate that ARP is a promising method for monitoring the process of the tissues thermal ablation, when HIFU is used.

This work was financially supported by the Ministry of Science and Higher Education of the Russian Federation, unique identifier No. RFMEFI57818X0263.

Evgen A. Barannik https://orcid.org/0000-0002-3962-9960

(D) Viktor I. Pupchenko https://orcid.org/0000-0001-8074-4867

DAnatoliy I. Marusenko https://orcid.org/0000-0001-8093-4732

(D) Oleksiy V. Knyazyev https://orcid.org/0000-0001-8738-8033

(1D)Aleksandr E. Berkovich https://orcid.org/0000-0002-0459-274X

\section{REFERENCES}

[1] A.D. Maxwell, G. Owens, H.S. Gurm, K. Ives, D.D. Myers and Z. Xu, Journal of vascular and interventional radiology, 22(3), 369-377 (2011), https://doi.org/10.1016/j.jvir.2010.10.007.

[2] W. Yang and Y Zhou, Ultrasonics Sonochemistry, 35(Part A), 152-160 (2017), https://doi.org/10.1016/j.ultsonch.2016.09.014.

[3] D. Suo, S. Guo, W. Lin, X. Jiang and Y. Jing, Phys. Med. Biol. 60, 7403-7418 (2015), https://doi.org/10.1088/0031-9155/ 60/18/7403.

[4] B. Petit, E. Gaud, D. Colevret, M. Arditi, F. Yan, F. Tranquart and E. Allémann, Ultrasound Med. Biol. 38(7), 1222-1233 (2012), https://doi.org/10.1016/j.ultrasmedbio.2012.02.023.

[5] R. Chen, D.G. Paeng, K.H. Lam, Q. Zhou, K.K. Shung, N. Matsuoka and M.S. Humayun, Journ. Med. Biol. Eng. 33(1), 103-110 (2013), https://www.ncbi.nlm.nih.gov/pmc/articles/PMC4209747/.

[6] R.J.E. van den Bijgaart, D.C. Eikelenboom, M. Hoogenboom, J.J. Fütterer, M.H. den Brok, G.J. Adema, Cancer Immunol. Immunother. 66(2), 247-258 (2017), https://doi.org/10.1007/s00262-016-1891-9.

[7] R. Cirincione, F.M. Di Maggio, G.I. Forte, L. Minafra, V. Bravatà, L. Castiglia, V. Cavalieri, G. Borasi, G. Russo, D. Lio, C. Messa, M.C. Gilardi and F.P. Cammarata, Ultrasound Med. Biol. 43(2), 398-411 (2017), https://doi.org/10.1016/j.ultrasmedbio.2016.09.020.

[8] N.N. Petrishchev, D.Y. Semyonov, A.Y. Tsibin, A.E. Berkovich and A.A. Bursian, Application of HIFU technology in angiology. Grekov's Bulletin of Surgery, 176(5), 101-105 (2017), https://doi.org/10.24884/0042-4625-2017-176-5-101-105. (In Russian).

[9] Berkovich A.E., Bursian A.A., Senchik K.U., Petrishchev N.N., Tsibin A.U. and Yukina G.U. Biomedical Engineering, 50(2), 96-99 (2016), https://doi.org/10.1007/s10527-016-9596-0.

[10] F. Wu, J. Acoust. Soc. Am. 134(2), 1695-1701 (2013), https://doi.org/10.1121/1.4812893.

[11] M. Wang, Y. Lei and Y. Zhou, Ultrasonics, 91(2), 134-149 (2019), https://doi.org/10.1016/j.ultras.2018.08.017.

[12] P.N.T. Wells, Eur. J. Ultrasound, 7(1), 3-8 (1998), https://doi.org/10.1016/S0929-8266(98)00006-8.

[13] E.A. Barannik, Ultrasonics, 39(2), 311-317 (2001), https://doi.org/10.1016/S0041-624X(01)00059-2.

[14] I.V. Skresanova and E.A. Barannik, Ultrasonics, 52(5), 676-684 (2012), https://doi.org/10.1016/j.ultras.2012.01.014.

[15] O.S. Matchenko and E.A. Barannik, Acoust. Phys. 63(5), 596-603 (2017), https://doi.org/10.1134/ S1063771017050086.

[16] N. Pulkovski, P. Schenk, N.A. Maffiuletti and A.F. Mannion, Muscle Nerve, 37(5), 638-649 (2008), https://doi.org/10.1002/mus.20996.

[17] E.A. Barannik, A.A. Kulibaba, S.A. Girnyk, D.A. Tolstoluzhskiy and I.V. Skresanova, J. Ultrasound Med. 31(12), 1959-1972 (2012), https://doi.org/10.7863/jum.2012.31.12.1959.

[18] J. Ophir, S.K. Alam, B.S. Garra, F. Kallel, E. Konofagou, T.A. Krouscop, C.R.B. Merritt, R. Righetti, R. Souchon, S. Srinivasan and T. Varghese, J. Med. Ultrasonics, 29(4), 155-171 (2003), https://doi.org/10.1007/BF02480847.

[19] C.R. Hill, J.C. Bamber and G.R. ter Haar, Physical Principles of Medical Ultrasound, (Chichester, John Wiley\&Sons, 2004), https://doi.org/10.1002/0470093978.

[20] K. Nightingale, Curr. Med. Imaging Rev. 7(4), 328-339 (2011), https://doi.org/10.2174/157340511798038657.

[21] K. Nightingale, M. Palmeri, R. Nightingale and G. Trahey, J. Acoust. Soc. Am. 110(1), 625-634 (2001), https://doi.org/10.1121/1.1378344.

[22] R.M.S. Sigrist, J. Liau, A. El Kaffas, M.C. Chammas and J.K. Willmann, Theranostics. 7(5), 1303-1329 (2017), https://doi.org/10.7150/thno.18650.

[23] E.A. Barannik, S.A. Girnyk, V.V. Tovstiak, A.I. Marusenko, S.Y. Emelianov and A.P. Sarvazyan, Ultrasonics, 40(1-8), 849-853 (2002), https://doi.org/10.1016/S0041-624X(02)00243-3. 
[24] E.A. Barannik, S.A. Girnyk, V.V. Tovstiak, A.I. Marusenko, V.A. Volokhov and A.P. Sarvazyan, J. Acoust. Soc. Am. 115(5Pt 1), 2358-2364 (2004), https://doi.org/10.1121/1.1698796.

[25] S.A. Girnyk, A.E. Barannik,.V. TovstiakV, D.A. Tolstoluzhsky and E.A. Barannik, Ultrasound Med. Biol. 35(5), 764-772 (2009), https://doi.org/10.1016/j.ultrasmedbio.2008.11.008.

[26] S. Girnyk, A. Barannik, E. Barannik, V. Tovstiak, A. Marusenko and V. Volokhov, Ultrasound Med. Biol. 32(2), 2011-2019 (2006), https://doi.org/10.1016/j.ultrasmedbio.2005.11.015.

[27] P.J. Fish, in: Physical Principles of Medical Ultrasonics, edited by C.R. Hill (Ellis Horwood, Chichester, 1986), pp. $338-376$.

[28] E.A. Barannik, The effect of ultrasound wave focusing on the mean-square width of the Doppler spectrum // Acoust. Phys. 40(2), 188-190 (1994), http://www.akzh.ru/pdf/1994_2_212-214.pdf. (in Russian)

[29] E.A. Barannik, Optimum resolution of pulsed Doppler systems, Acoust. Phys. 43(4), 387-390 (1997), http://www.akzh.ru/pdf/1997 4 453-457.pdf. (in Russian)

[30] H. Hasegawa, H. Kanai, Yo. Koiwa and J.P. Butler, Jpn. J. Appl. Phys. 42(5B), 3255-3261 (2003), https://doi.org/10.1143/JJAP.42.3255.

[31] E.A. Barannik, in: Proceedings of the $5^{\text {th }}$ World Congress on Ultrasonics, (Paris, France, 2003), pp. 397-400.

\section{ПРОСТОРОВА РОЗДІЛЬНА ЗДАТНІСТЬ ТА ТОЧНІСТЬ ВИМІРЮВАНЬ УЛЬТРАЗВУКОВОЇ ДІАГНОСТИЧНОЇ СИСТЕМИ ПРИ АКУСТИЧНІЙ ВІДАЛЕНІЙ ПАЛЬПАЦІЇ ЗА ДОПОМОГОЮ СФОКУСОВАНОГО УЛЬТРАЗВУКУ ВИСОКОЇ ІНТЕНСИВНОСТІ \\ Є.О. Баранник ${ }^{1}$, В.І. Пупченко ${ }^{2}$, А.І. Марусенко ${ }^{2}$, О.В. Князев ${ }^{2}$, І.М. Цибін ${ }^{3}$, О.Ю. Беркович ${ }^{4}$ \\ ${ }^{1}$ Харківський національний університет імені В.Н. Каразіна, Харків, Украйна \\ ${ }^{2}$ ТОВ «Ультрасайн», Харків, Україна \\ ${ }^{3} A T \ll Н В Ф$ БІОСС», Москва, Росія}

${ }^{4}$ ФГАОУ ВО «Санкт-Петербурзький політехнічний університет Петра Великого», Санкт-Петербург, Росія

В даній роботі теоретично та експериментально досліджені просторова роздільна здатність та точність вимірювань ультразвукової діагностичної системи при акустичній віддаленій пальпації (АВП) за допомогою сфокусованого ультразвуку високої інтенсивності (СУВI). Запропонована фізична модель, яка описує особливості АВП з урахуванням віддаленого характеру ультразвукового допплерівського зондування локального руху м'яких тканин, що викликаний силою радіаційного тиску імпульсу СУВІ. Показано, що з урахуванням зроблених для спрощення припущень виводи моделі добре узгоджуються з результатами проведених експериментів щодо вимірювання величини переміщень під впливом СУВІ. Доведена, зокрема, нетривіальна залежність величини переміщень, що вимірюються допплерівським методом, від глибини зондування та ступені фокусування падаючого та відбитого пучків хвиль. Експериментально досліджена поперечна роздільна здатність при АВП у випадку зондування неоднорідного за модулем Юнга середовища, а також вплив шуму і перешкод на точність вимірювань та роздільну здатність. Зроблений висновок про те, що поперечна роздільна здатність при АВП визначається параметрами локальної області руху і може бути суттєво кращою, ніж власна роздільна здатність ультразвукової системи при В-режимі діагностики. Отримані результаті свідчать про перспективність АВП для моніторингу процесу термічної абляції м'яких тканин за допомогою СУВI.

КЛЮЧОВІ СЛОВА: АВП, СУВІ, абляція, допплерівське зондування, еластографія, просторова роздільна здатність, точність вимірювань.

\section{ПРОСТРАНСТВЕННАЯ РАЗРЕШАЮЩАЯ СПОСОБНОСТЬ И ТОЧНОСТЬ ИЗМЕРЕНИЙ УЛЬТРАЗВУКОВОЙ ДИАГНОСТИЧЕСКОЙ СИСТЕМЫ ПРИ АКУСТИЧЕСКОЙ УДАЛЕННОЙ ПАЛЬПАЦИИ С ПОМОЩЬЮ ФОКУСИРОВАННОГО УЛЬТРАЗВУКА ВЫСОКОЙ ИНТЕНСИВНОСТИ}

Е.А. Баранник ${ }^{1 *}$, В.И. Пупченко ${ }^{2}$, А.И. Марусенко ${ }^{2}$, А.В. Князев ${ }^{2}$, И.М. Цыбин ${ }^{3}$, А.Е. Беркович ${ }^{4}$

${ }^{1}$ Харьковский национальный университет имени В.Н. Каразина, Харьков, Украина

${ }^{2} О О О$ «Ультрасайн», Харьков, Украина

${ }^{3}$ АО НПФ «БИОСС», Москва, Россия

${ }^{4}$ ФГАОУ ВО «Санкт-Петербургский политехнический университет Петра Великого», Санкт-Петербург, Россия

В настоящей работе теоретически и экспериментально исследованы пространственная разрешающая способность и точность измерений ультразвуковой диагностической системы при акустической удаленной пальпации (АУП) с помощью фокусированного ультразвука высокой интенсивности (ФУВИ). Предложена физическая модель, которая описывает особенности АУП с учетом удаленного характера ультразвукового допплеровского зондирования локального движения мягких тканей, вызванного силой радиационного давления импульса ФУВИ. Показано, что с учетом сделанных упрощающих предположений выводы модели хорошо согласуются с результатами проведенных экспериментов по измерению величины перемещений под действием ФУВИ. Доказана, в частности, нетривиальная зависимость величины измеряемых допплеровским методом перемещений от глубины зондирования и степени фокусировки падающего и отраженного пучков волн. Экспериментально исследована поперечная разрешающая способность при АУП в случае зондирования неоднородной по модулю Юнга среды, а также влияние шумов и помех на точность измерений и разрешающую способность. Сделан вывод о том, что поперечная разрешающая способность при АУП определяется параметрами локальной области движения и может быть существенно лучше, чем собственная разрешающая способность ультразвуковой системы при В-режиме диагностики. Полученные результаты свидетельствуют о перспективности АУП для мониторинга процесса термической абляции мягких тканей с помощью ФУВИ.

КЛЮЧЕВЫЕ СЛОВА: АУП, ФУВИ, абляция, допплеровское зондирование, эластография, пространственное разрешение, точность измерений 